\title{
The international political economy of nature and society: from climate emergency to climate justice in our common home
}

\begin{abstract}
Longitudinal scientific evidence proves beyond any reasonable doubt that the problem of climate change is reaching a point of no return, upon which Earthly and human survival depends. The major contributors of climate change include industry, transportation, agriculture, and consumers, over which corporate globalization controls, which consume fossil fuels, such as oil, coal, and gas that produce greenhouse gases. Climate change impacts access to clean water, human health, forests, coastal areas, biodiversity, and agriculture. Our tasks ahead include: 1) exposing and opposing flawed economic, political, social, cultural, and security models that destroy nature, cause mal-development, and widening the gap between the rich and the poor and 2) proposing new cooperative models that put sustainability and equality-nature and people - first, especially the poor and the oppressed, before profits.
\end{abstract}

Keywords

Climate. Greenhouse gas emissions. International political economy. Nature and society. Poverty.

\section{INTRODUCTION}

Profound contradictions exist in the world today (Merchant, 1992). There is a tension: 1) between economic forces of production and the condition of Nature; 2) between production and biological and social reproduction; and 3) between the $1 \%$ and the $99 \%$. Worse, globalized corporate entities spend millions to fund lobbyists and journalists to claim that climate change is a hoax (Readfearn, 2016).

Human activities in general as well as greedy and profit-seeking industrial and agribusiness production in particular lead to emitting excessive carbon dioxide and other greenhouse gases to Nature, leading to an increase in global temperature. Hence, the crisis of climate change today is anthropogenic or human-induced. The problem lies with globalized corporations and agri-business which control resources, influence governments, exploit cheap labor, and destroy Nature. Globalization benefits the 1\%. Few rich benefit from exploiting Nature which causes destruction of Nature and the suffering of the majority, including women and children. If we continue the status quo of he direction towards which we are heading

Some of the causes of the destruction of Nature include the following: urban excess; transnational corporation operations; green revolution; chemical pesticides and fertilizers; overfishing; over-use of groundwater; over-exploitation of natural resources; the obsolescence model of economic growth and supply-side economics (Global Warming, 2009).

\footnotetext{
${ }^{1}$ Doutor em Direitos Humanos e Educação para a Construção da Paz. Mestre em Ciências Políticas e Estudos Asiáticos. Diretor executivo do Programa para a Construção da Paz da Conferência Cristã da Ásia e instrutor convidado no doutorado do Instituto de Religião, Cultura e Paz da Universidade Payap. Contato: reyty1@gmail.com.
} 
This article raises the following questions: What are the contours, causes, and impacts of the climate emergency? Why is the climate emergency a question of justice? What are the tasks ahead to mitigate the climate crisis?

The objectives of this paper are to: depict the contours of the climate emergency; identify the causes of climate emergency; shed light on the impacts of climate crisis; explain the reason for which the climate emergency is a matter of justice; and, propose ways by which to mitigate climate crisis and its impact.

\section{CONCEPTUAL EVOLUTION}

When scientists started to identify a longitudinal trend of changes in global temperature, they initially used the term global warming, which points to the human-induced rise in temperature as empirically measured over a long period of time. However, the term fell into disrepute, when doubters attacked the concept. Thereafter, the word climate change was employed, with wide acceptance from all camps (Funk and Kennedy, 2019). However, when the situation became acute, scientists began to use the word climate crisis to indicate the gravity of the situation (CIEL, 1990). As government action becomes imperative, both politicians and nongovernmental climate activists called for a climate emergency declaration and a climate emergency plan to indicate the urgent need for an immediate response to a long-standing problem in order to slow down and decrease climate change.

FIGURE 1 - CHANGES IN THE USE OF CONCEPTS TO REFER TO THE SAME PHENOMENON

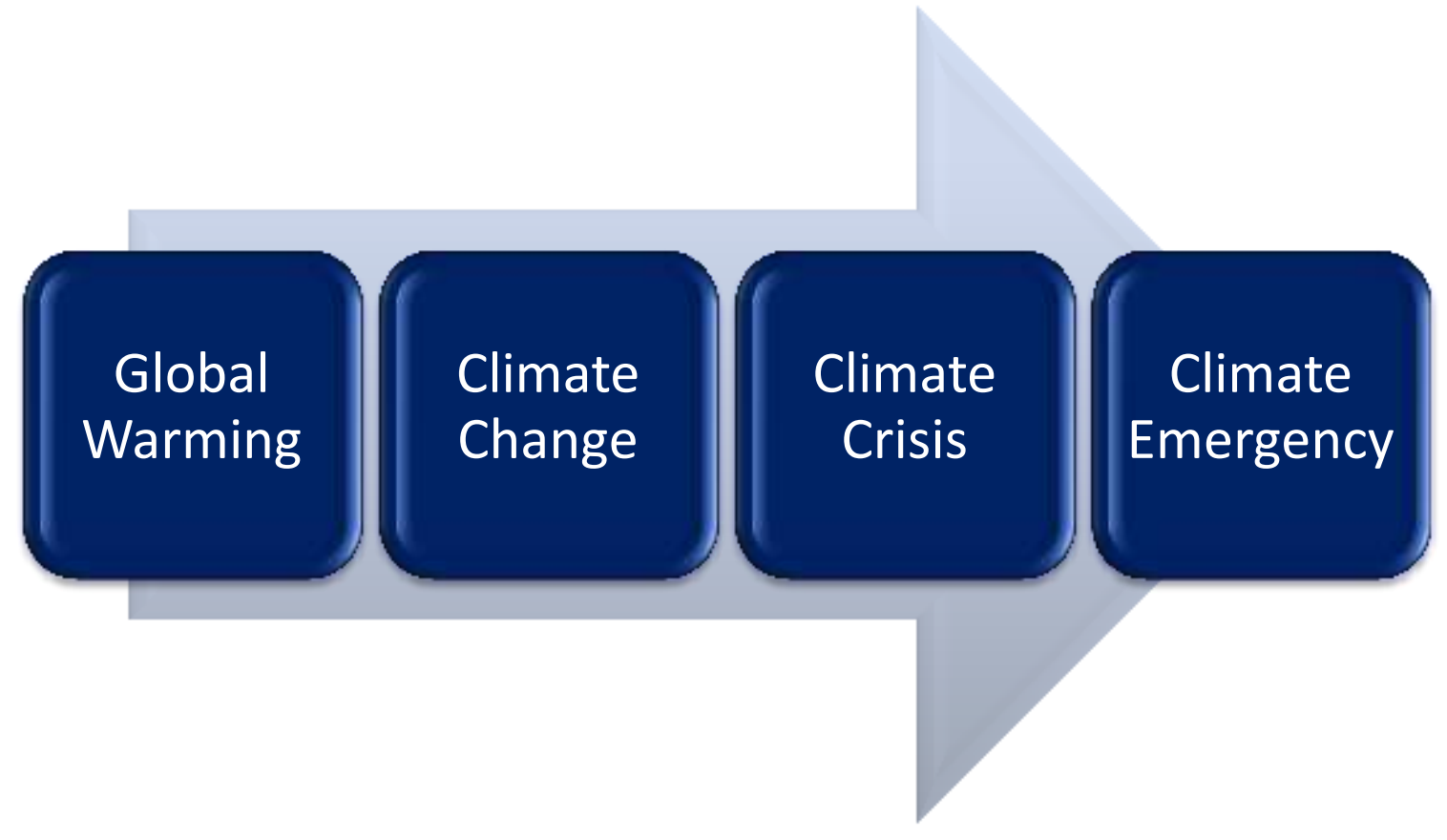




\section{Revista Brasileira de Diálogo Ecumênico e Inter-religioso}

\section{FRAMEWORK OF ANALYSIS}

Pope Francis (LS 25) proclaimed in Laudato si' that climate change "is a global problem with grave implications: environmental, social, economic, political and for the distribution of goods... Its worst impact will probably be felt by developing countries in coming decades." This statement clearly establishes international political economy as the framework upon which to study nature and society, stressing the need to have a dialectical and holistic view of the unity and conflict between Nature and society, that takes into consideration the past, development, current situation, and implications for transformation in the future. Furthermore, we have to take into account the harmony and tension between people and systems of different economic, political, cultural, and philosophical backgrounds and systems (Ty, 2011). Climate change encompasses ecological, social, economic, political, and ethical considerations.

The United Nations (U.N.) has developed several principles throughout the years and decades about the linkage and interdependence among different facets of life. For example, the Rio Declaration on Environment and Development (U.N., 1992a) helped promote sustainable development by providing guidelines to government. The Agenda (U.N, 1992b), which was an output of the U.N. Conference on Environment and Development (or Earth Summit) is an action plan that promotes sustainable development. The Ksentini Report (U.N., 1994) officially recognized the relationship between human rights and the environment or the link between justice and Nature.

Surely, there are many international laws protecting nature. However, many governments encourage economic growth at the expense of Nature and human rights, but yet claim to promote balanced growth (Priebe \& Steinle, 2013).

\section{FINDINGS}

\subsection{Contours of the climate emergency}

Based on climate scientists' global observations, climate change broke records again as well as hits harder and sooner than forecasted (WMO, No. 15, 2019 Nov 25). The World Meteorological Organization (WMO) of the United Nations (2019) asserts that the concentrations of heat-trapping greenhouse gases (GHS) reached a new record high. Carbon dioxide emissions exceeded $147 \%$ pre-industrial levels; methane, 259\%; and, nitrous oxide, $123 \%$ (WMO, No. 15, 2019). Human-induced global warming has now triggered 150,000 deaths and 5 million incidents of disease annually from additional diarrhea and malaria, mostly in the Global South (Patz et. Al., 2005). On November 5, 2019, 11,000 scientists from all over the world made headlines in their joint statement: "The climate crisis has arrived and is accelerating faster than most scientists expected. It is more severe than anticipated, threatening natural ecosystems and the fate of humanity. (Guardian, 2019 Nov. 5).

A global crisis is happening right now. We live in a world in which the majority is composed of sheep where wolves rule. "Issues such as trade and the environment, biodiversity Caminhos de Diálogo, Curitiba, ano 7, n. 11, p. 172-186, jul./dez. 2019 
and climate change, have divided the global North and South along different lines than commonly understood and are being addressed by parceling out global resources" (Fahn, 2003, p. vi). "Profiting from death, devastation, and destruction is the norm" (Todhunter, 2016). The United Nations notes that the global destruction of nature is on a fast track (Germanos, 2016). Inequality deepens, politics favors the $1 \%$, and the Earth is wounded. Climate change has reached a level of climate crisis and even climate emergency.

Monoculture, urbanization, and habitat destruction all contribute to deforestation and climate change (Schwägerl, 2016). As of July 11, 2016 morning, 2,741,230 hectares of forests are lost, 3,690,437 hectares of land are lost to soil erosion, 19,620,181,260 tons of carbon dioxide $\left(\mathrm{CO}_{2}\right)$ emissions, 6,325,276 hectares of land fell prey to desertification this year, and $5,161,625$ tons of toxic chemicals are released in the environment (Worldometers, 2016). Every hour, 3.7 million barrels of oil, 932,000 tons of coal, and 395 million cubic meters of natural gas are taken from the Earth; and 4.1 million tons of carbon dioxide are released into the atmosphere (Jamail, 2016).

In the coldest period of the last Ice Age, 4.5 degrees Celsius below our current norm is the Earth's average temperature (Climate Reality Project, 2016). The Paris climate conference in December 2015 produced the Paris Agreement (2016) within the United Nations Framework Convention on Climate Change, which contend with greenhouse gas reduction, beginning in 2020. The Paris conference pledged to keep warming "within below 2 degrees Celsius" $\left({ }^{\circ} \mathrm{C}\right)$ and to "pursue efforts" to limit it to " $1.5^{\circ} \mathrm{C}$," as opposed to the $2^{\circ} \mathrm{C}$ of the Copenhagen agreement six years ago(Guardian, 2015 December 12).

Curbing warming by $1.5^{\circ} \mathrm{C}$ can prevent the formation of ice-free Arctic in summer; save the Amazon rainforest; prevent Siberian tundra from melting which will release methane, and save coastal areas and islands from permanent flooding (Pearce, 2016). Oxfam (2016b) stated that companies have to make drastic emissions cut, lest the Paris Agreement's net-zero emissions goal by the middle of the century and of limiting global warming to $1.5^{\circ} \mathrm{C}$ will not be met.

However, we have reached a disturbing climate change milestone. For the first time in recorded history, even for a few hours, we have crossed the line, as the temperature in the northern hemisphere was 2 degrees Celsius well above the "normal" (McKibben, 2016). April 2016 was the hottest April in recorded history. NASA indicated that April was $1.11^{\circ} \mathrm{C}$ above the 1951-1980 average by $0.24^{\circ} \mathrm{C}$ (Mosbergen, 2016). Atmospheric carbon dioxide concentration has passed the point of no return (Jamail, 2016). Atmospheric carbon dioxide may not drop below 400 parts per million within our lifetimes (Yale, 2016). 
Revista Brasileira de Diálogo Ecumênico e Inter-religioso

\section{CAUSES}

\subsection{North-South relations}

The root cause of the entire climate and other related woes today in the world is the neoliberal capitalist economic system that promotes trade liberalization, deregulation, and privatization, which leads to the wanton destruction of nature for profit, anarchy of production, and overproduction. This economic system upholds socialism for the few rich but capitalism for the majority poor. The economic growth model with the concomitant profit orientation and wealth accumulation are the root causes of the climate emergency. Two major problems today are the threat of nuclear catastrophe and climate change (Chomsky, 2013). Oxfam reported that in 2013, only 85 billionaires have the same wealth as 3.5 billion poorest $50 \%$ people in the world (Oxfam, 2014); in 2015 only 62 persons hold the same wealth as half of the 7.2 billion people on Earth (Oxfam, 2016a); in 2016 only 8 men own the same wealth as 3.6 billion people or half of humanity (Oxfam, 2017), later statistically corrected as 61 billionaires; in 2017 the richest $1 \%$ earned eighty two percent $(83 \%)$ of the world's wealth (Oxfam, 2018) in which 42 persons own the same wealth as 3.7 billion poorest people on Earth (Guardian, 2018 January 22); and, in 2018 only 26 billionaires have the same wealth as half the planet of 3.8 billion people (Guardian, 2019 January 21). The disproportionate carbon footprint of the Global North is undeniable. The World Council of Churches (WCC, 2012) noted that the Global North (20\%) accounts for $90 \%$ of yearly greenhouse gas emissions over the past 100 years through fossil fuel burning (coal, oil, gas) which produce greenhouse gases. The major users and producers of greenhouse gases include energy production, industry, transportation, agriculture, and consumers (EPA, 2016). Note, however, that corporate and economic globalization control over Nature and people are almost absolute.

The climate emergency we are facing today was not an accident. As early as 1982, ExxonMobil scientists predicted climate change but the company spent millions on their misinformation campaign about uncertainty (Yes!, 2019 May 15). We live in a dystopia where corporations control the political elites who formulate and implement profit-oriented policies at the expense of Nature and people (Klein, 2018). The basic right to water is now reduced to the logos and the greed of giant corporations (Klein, 2010). Corporations are cashing in on the sale of bottled water, drinks, and junk food that lead to environmental catastrophes (Klein, 2008). The root cause of global warming is not just carbon emission as such but the inherently exploitative unbridled capitalist system on a deeper level, which is blind to carbon emissions (Klein, 2015). Through government-sponsored economic globalization, transnational corporations move from the now giant mono-cultural agri-business and mostly post-industrial North to the agricultural and industrial South to avoid paying large amount of taxes, avoid strict environmental laws, thereby destroying Nature and transferring waste and pollution, as well as cause unemployment locally and the exploitation of cheap labor abroad. Pollution is merely transferred from one region to another in the same planet. With free trade, governments cannot Caminhos de Diálogo, Curitiba, ano 7, n. 11, p. 172-186, jul./dez. 2019 176 ISSN 2595-8208 
impose stiff environmental laws. Southern rainforests are destroyed for exotic wood and for the North. Serving as the lungs of the Earth, trees in rainforests including the Amazon regulate the climate; but in Peru and Ecuador, the Amazon is sectioned for oil drilling (Guardian, 2015). Mass poverty and the destruction of Nature result.

The production of a new and disposable gadget which we purchase has impact on destroying Nature, pollution, and workers. The poor, marginalized, and dispossessed are always most affected. Our throwaway society experiences a crisis of overproduction and overconsumption of disposable commodities which destroys Nature as well as produce waste and pollution from which the poor in the poor and rich countries, including indigenous and minority communities, suffer the most. The rich have bottled water and air conditioners. The poor suffer the most from economic, political, and cultural domination as well as damage to Nature. Such is the situation of environmental racism in the world today. Greed and profit reign supreme over people and Nature.

Countless mining operations, agri-business, and large plantations engage in land grabs, affecting indigenous peoples, peasants, workers, and farm workers. Hence, economic, political, and ecological matters and human rights are closely linked (Forest Peoples Programme, 2016).

\subsection{Asia-Pacific region}

Global warming will hit people, land, and economies of Asia hardest on Earth (ADB, 2014): floods, famine, and rising sea level will affect hundreds of millions, the majority of whom will be in East, Southeast, and South Asia, including small island countries (Guardian, 2016). The United Nations (2016) states that in the Asia-Pacific region: "Increasing unsustainable consumption patterns have led to worsening air pollution, water scarcity and waste generation, threatening human and environmental health. Increased demand for fossil fuels and natural resources - extensive agriculture, palm oil and rubber plantations, aquaculture and the illegal trade in wildlife - are causing environmental degradation and biodiversity loss" (Germanos, 2016).

In Asia, increased urbanization, the destruction of coral reefs as well as of forest lands for large plantations, such as palm oil, cause the release of massive amounts of carbon into the atmosphere (Hershberger, 2014).

\subsection{Food}

In the U.S. agricultural system, organic farmers have to pay fees for "certification," whereas taxpayer money is used to subsidize the use of Genetically Modified Organisms (GMOs) which globalized biotech companies aggressively promote. Five common foods-rice, soy, corn, wheat, and palm oil-produce more greenhouse gas emissions than almost all countries, except China and the U.S. (Oxfam, 2016b). 


\section{Revista Brasileira de Diálogo Ecumênico e Inter-religioso}

Over 400 gallons of water is required to produce one hamburger (Atlantic, 2016). About $14.5 \%$ of greenhouse gases come from farming meat and dairy producing animals, which is more than all the vehicles, airplanes, and ships on Earth. If unabated, carbon emissions could rise to $73 \%$ by 2050 (Guardian, 2015).

\section{IMPACTS}

Globalized corporations are engaged in mining, logging, deforestation, and plantations, which destroy Nature and release enormous amounts of greenhouse gases and sometimes involving land grabs of indigenous peoples and of local farmers as well as committing human rights violations and destroying Nature (Fahn, 2003). For this reason, we need to gain "insight into the relationship between the sustainable development and democracy, the crippling impact of corruption, and the environmental challenges facing us all" (Fahn, 2003, back cover).

Climate change affects human health, coastal areas, biodiversity, agriculture, access to clean water, and forests. Climate change leads to extreme temperatures, bringing about heat waves, droughts, floods, and rising sea levels. Rising sea levels drown five Pacific islands (D’Angelo, 2016). "Economic and trade policies have been a major contributor to" the plight of migrant labor (Conniff, 2016) and climate refugees (Baker, 2015). In fact, climate change, such as drought in Syria, causes the surge of migrants to Europe (Baker, 2015).

The problem with the globalized economic growth model is that it is based on greed, profit, competition, exploitation of Nature, exploitation of cheap labor, obsolescence, and overproduction. Every time we get a new gadget, such as the state-of-the-art cellphone, or any consumer good (diamond, coffee, or carpet), new materials have to be mined, which cause pollution, manufactured, which cause the release of greenhouse gases, and the poor, marginalized, and dispossessed are always affected, including the indigenous peoples, peasants, workers, women, and children.

In general, climate change will lead to loss of biodiversity, deforestation, floods, landslides, decreased access to clean water (Global Warming, 2009). In Southeast Asia, climate change will bring about 1) disasters (heat waves, droughts, floods, and storms that threaten lives and property), 2) thirst (potable water will be less available when the Himalayan glaciers melt too fast), and 3) hunger (droughts, floods, and extreme weather destroy farmlands and crops) (Greenpeace, 2016).

\section{CLIMATE EMERGENCY IS A MATTER OF JUSTICE}

Non-governmental organizations all over the world call for climate justice, as there is a direct relationship between climate change on the one hand and inequality and poverty on the other hand. The poor individuals who and the poor countries in the Global South which least contribute to negative climate change suffer the gravest losses, damages, and consequences of climate change; thus, the rich must foot the bill for impact on the Global South (Guardian, 2019 Caminhos de Diálogo, Curitiba, ano 7, n. 11, p. 172-186, jul./dez. 2019 178 ISSN 2595-8208 
December 1). Clearly, just solutions to the climate crisis ought to take into considerations matters related to human rights, equality, and historical responsibility for climate change. Clearly, climate change is an ethical and political matter, not just an ecological matter as such, while recognizing its intensity. Hence, there is a need for a justice perspective in which climate justice is an integral component of eco-justice. To be sure, money talks. The Intergovernmental Panel on Climate Change (IPCC, 2019 states that poor individuals and communities are more vulnerable to pollution and environmental disasters, while the rich can always move to a safer and higher ground, buy bottled water, and use air conditioner. Poor women of color in far-flung peasant and indigenous villages have to go farther and farther to collect drinking water. The poor in both the Global North and the Global South take more time to recuperate from effects of higher temperatures, air quality, extreme weather, planting, and harvesting, if at all. There is an intersection of class, income, wealth, power, gender, ethnicity, and color in times of climatic havoc. Such is the nature of environmental racism. Reaching a critical point, the climate emergency cannot be treated merely as an environmental or physical issue, but as a matter of environmental ethics in the form of eco-justice, environmental justice, or climate ethics. Climate crisis policy and action must take into account their impact on equality, human rights, society, nature, and the common heritage of humanity. Climate emergency must be viewed from an ethical, political, and legal point of view. Each of us has to take responsibility and perform our roles: consumers to use water bottles, which is necessary but not sufficient, while society has to construct a new, just, bio- and eco-centric social system which is neither anthropocentric nor profit-seeking, but rather helps mitigate climate change. The disadvantaged groups in society must take part in policy making and planning climate actions so that they are empowered in deciding their future. Social and economic inequalities must be organized so that the least advantaged Global South gets assistance from the Global North in mitigating greenhouse gas emissions.

Despite its better-than-thou pronouncements about the climate emergency, the Global North has a huge negative environmental footprint throughout its colonial and industrial history. For this reason, the Global North has disproportionately contributed to the causes and effects of the climate crisis and emergency, while the Global South which as least done harm to the climate historically suffer first and the most from the effects of the climate crisis. The economic growth development model of "modernization" marked by commodification, surplus production, and profit orientation does great harm to nature and negatively impacts climate change. In fact, there is a tension and contradiction between the social development goals (SDGs) of economic growth which leads to more greenhouse gas emissions that aggravates the climate crisis on the one hand and climate action on the other hand. In an effort to quantify emissions debt, more than fifty poorest countries in the world proposed the notion of climate debt or ecological debt to the United Nations Framework Convention on Climate Change (UNFCC), which include the concepts of adaptation debt and emissions debt (ActionAid, 2009). 


\section{Revista Brasileira de Diálogo Ecumênico e Inter-religioso}

Emissions debt refers to the Global North's over-utilization and waning capacity to absorb greenhouse gas (GHG) emissions, thereby denying the Global South the ability to develop their economies the way the Global North did. Adaptation debt refers to the negative impact of such excessive emissions which cause damage and lost development opportunities for the Global South. For these reasons, the Global North have a duty to tackle the climate emergency by just solutions, namely emissions reduction and foreign debt cancellation (World Development Movement, 2009).

\section{ALTERNATIVES}

There have been quantum leaps in science and technology. Computers used to be the size of a whole floor in the 1960s. Now, we have palm-sized tablet computers. However, we are still using fossil fuels, while we already know that renewable energy is abundant and readily available. The $1.5 \mathrm{C}$ limit can be achieved only with rapid and far-reaching disruptive, planned, and coordinated transformations on an unprecedented level in history in the global economy. The Time for change is now. However, greed reduces Nature into "resources" to be mastered, exploited, controlled, destroyed and used for profit and "economic growth." Sure, we need research and space exploration. However, planning and spending fortunes to colonize the moon and Mars spells pessimism and submission to the death of our common home. Instead of wasting resources to plan and colonize space, we need to clean our own home to ensure next generations can continue to have a quality life in our common home on Earth. Only swift transformational changes can fend off climate catastrophe in the world.

Traditional security focuses on military power during the Cold War. Non-traditional security deals with a host of issues, including climate change, resource scarcity, natural disaster, food security, and transnational crime (Priebe \& Steinle, 2013). Nevertheless, technological fixes and market incentives alone are not sufficient. Economic reforms are not enough. We need an overhaul of our ecological, economic, political, cultural, and security models that promote life and justice. Protecting nature go hand in hand with economic, political, and cultural justice. We live in a state of climate emergency. Petroleum needing to be kept in the ground, we need to convert to renewable energy, while at the same time ensuring environment-friendly, life-giving, and meaningful work for healthy peasants and workers who will flourish. Now is the time for climate activists, climate action, climate strike, Friday for the Future, and Extinction Rebellion, as the youth around the world demand for action here and now. Mass democratic movements demand actions for change, including a New Green Deal (Klein, 2019). Pope Francis calls Time Magazine Person of the Year Greta Thunberg a "great witness" of Church's environmental teaching (Crux, 2019 December 12). The climate leaders today are the world's youth.

Vandana Shiva (2013) remarked: "Political struggles of women, peasants, and tribals based on ecology in countries like India are far more acute and urgent since they are rooted in immediate threat to the options for survival for the vast majority of the people, posed by Caminhos de Diálogo, Curitiba, ano 7, n. 11, p. 172-186, jul./dez. 2019 
resource intensive and resource wasteful economic growth for the benefit of a minority" (In Plant, Ed., p. 87). One option is degrowth, focusing instead of compassion, caring, and sharing. Instead of economic growth, measuring of development could include, among others, equality, fairness, happiness, women empowerment, sustainability, and the protection of Nature. Protect and expand forest areas, as they affect global climate, rainfall patterns, and the availability of fresh water.

In response to the climate emergency, the United Nations (UN) has been organizing climate summits with some achievements. In 1996, world leaders admitted the human induced nature of climate change, as a result of which they created the Kyoto Protocol and the Paris Agreement. They also set up the Green Climate Fund, the purpose of which is to assist impacted countries to adapt to changes in the climate. Climate researchers assert that global curve of emissions must be restrained by 2020 at the latest; but in 2018, greenhouse gas emissions increased by $0.6 \%$, thus, we are currently headed at the wrong direction (Rockström, 2017). These scientific valuations emphasize the necessity of urgent action to decrease global emissions so as to avert the worst impacts of the climate emergency. The toll from extreme weather, air pollution, rising sea levels, and forced migration validate that this is a current reality encompassing almost all of humanity. The United Nations Framework Convention on Climate Change (UNFCCC, 2019) supports collaborative actions of governments to fight climate change and its impact on human beings and the ecosystems as a contribution to a sustainable world.

The U.N. leads The $25^{\text {th }}$ Annual Conference of the Parties (COP25), which is a climate summit, in Madrid in December 2019. Its threefold goals includes the following: 1) to reduce emissions by $45 \%$ by 2030 in order to have net-zero carbon footprint by 2050; and, 3) to prevent global temperature from rising above 1.5 C. However, global carbon dioxide emission hits its highest: However, lack of a sense of urgency inside the COP25 meeting rooms in Madrid left climate activists frustrated (Guardian, 2019 December 9a). Rich economies, which are the biggest emitters of heat-trapping greenhouse gases that cause climate disaster, block all progress at the COP25 talks, during which U.N. guards kicked out climate activists (Intercept, 2019 December 19). Climate activists were furious and the U.N. Secretary-General Antonio Guterres himself was disappointed with the outcome of COP25, as rich countries, including the U.S., refused to agree on mandatory measures to avert climate catastrophe but rather stonewalled $\$ 300$ billion climate relief fund (In These Times, 2019 December 13). By all measures, COP25 was a dismal failure. Despite the youth protesting for the past two years, greenhouse gas emissions have increased unrelentingly. Polluters proceed with business as usual. For its part, the European Commission unveils a Green New Deal which the European Union will rouse (Guardian, 2019 Dec. 9b). 


\section{CONCLUSION}

Flawed economic, political, cultural, and security models not only cause maldevelopment and the widening gap between the rich and the poor but also the use of fossil fuels that cause the destruction of Nature leading to greenhouse gases that stimulate climate change: in a word, eco-injustice.

Climate change issues are borderless problems that require local, multilateral, and transnational solutions with the active role of civil society and governments. Structural problems require structural changes. We need to mainstream alternative renewable energy sources as well as to link together social justice and the concern for Nature.
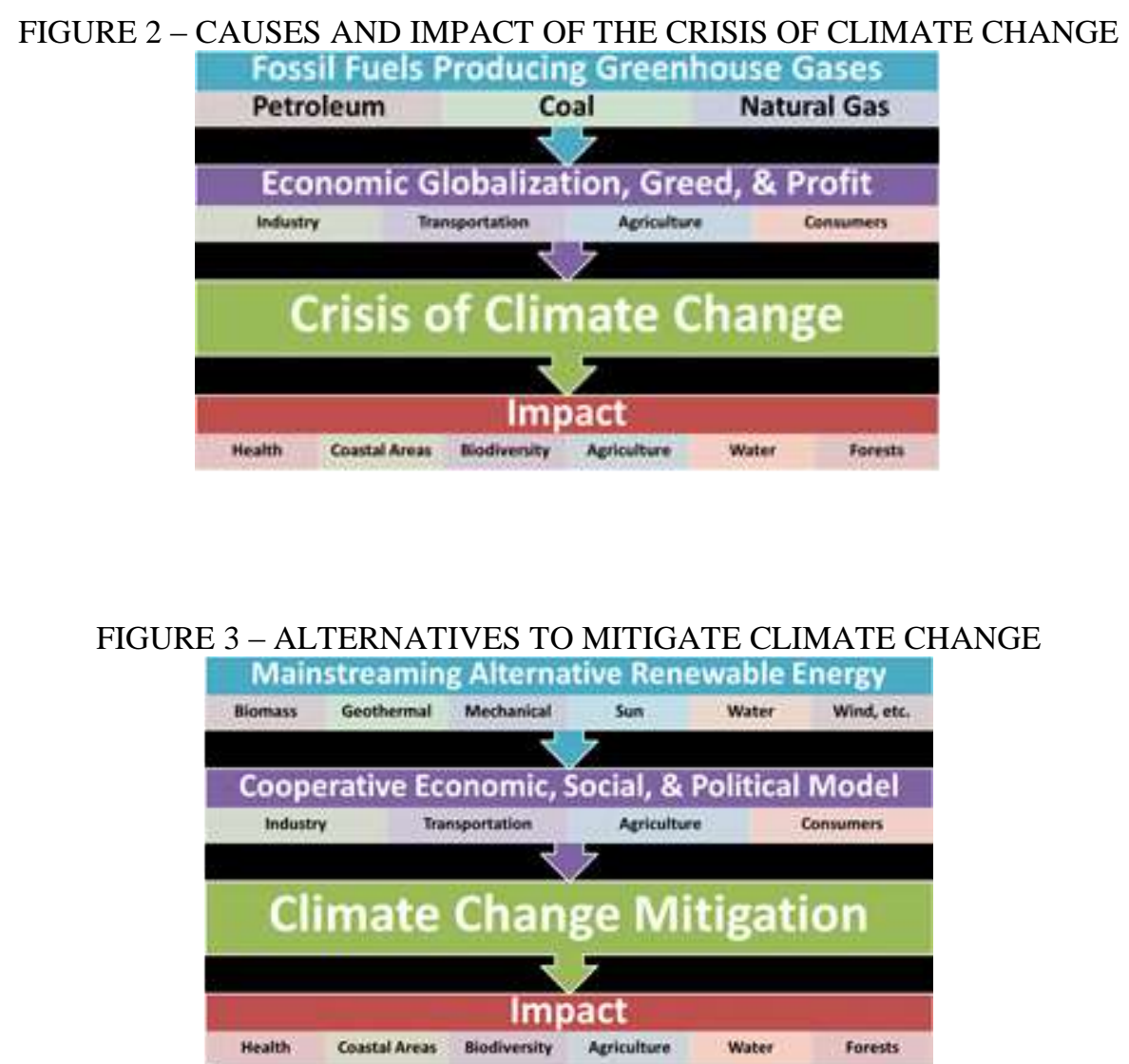

In the name of economic growth and progress, human beings and Nature are being exploited and destroyed. Climate change issues are borderless: greenhouse gas emissions, rainforest destruction, and rising sea levels (Priebe \& Steinle, 2013). Hence, we need to develop new models that promote, protect, and nurture people and Nature. Give voice to the voiceless. Listen to those most affected by climate change. Talk is necessary but not sufficient. We need action, not just lip service. "The world cannot wait: climate change is happening" (World Council of Churches, 2014, pp. 68, 72).

Conservatives say: "Take personal responsibility. You are at fault for buying bottled water. Use a water bottle." Liberals say: "Take social responsibility. Be a good steward by being good to the environment." Radicals say: "Instead of blaming the consumers, workers, peasants, Caminhos de Diálogo, Curitiba, ano 7, n. 11, p. 172-186, jul./dez. 2019 
and indigenous peoples again, take structural responsibility. Change the system that promotes commodity fetishism, alienation, greed, profit, and exploitation of humans and Nature. Construct a system that promotes caring, sharing, biocentrism, and eco-centrism." In truth, all of us have a role to play to avert the climate catastrophe. We need climate action at all levels, regardless of ideology, politics, and organization. However, changing our actions on the micro and individual level, such as using water bottles and not using plastic bags, though necessary, is not sufficient. Micro-consumerism for which we buy more things, such as water bottles, does not solve the problem. Rather, we need to pierce the heart of the beast and overthrow the economic, political, and cultural system that eats up the Planet with the neoliberal economics of perpetual growth measured in terms of gross domestic product (GDP) which contradicts the rewilding, preservation, and regeneration of nature.

This is the critical time during which we need a green New Deal (Klein, 2019). Ordinary folks at the grassroots level take the lead in speaking truth to power (Goodman \& Goodman, 2008). Through conscientization (Freire, 1973), we need to inject new blood into the political process who will promote social change that advances both equality and sustainability. Make the global commons, including water, part of our inalienable human rights, as well as grow trees and plants for the greening of cities, countryside, and forested areas (Roberts, 2016). Stop fracking, destruction of forests for fossil fuel and agri-business, Interrupt climate change before it interrupts Nature and society. We must listen to the indigenous wisdom and have leadership from the margins. The United Methodist Church observes: “.... we cannot continue to ignore those struggling at the forefront of climate change in communities relegated to the political margins. Not only have their environments been impacted by the production and consumption of resources for our industrialized world, but they also represent the leading edge of our own environmental future. ..Fortunately, the current grassroots struggles for climate justice are increasingly spearheaded by the impacted peoples themselves-low income people, people of color, and indigenous peoples" (Kris \& Laccetti, 2016). Put Nature and people first, especially the oppressed and the poor, before profits. Climate justice cannot wait. Millions die as a result of climate crisis. A radical transformation of our economic, political, and cultural systems to allay the impact of the climate emergency is needed soonest. Our clarion calls today are to put nature and people above profit and greed as well as to uphold caring and sharing, not exploitation and destruction. The time to act is now.

\section{REFERENCES}

ActionAid International. (2009 October). Rich countries' 'climate debt' and how they can repay it. Johannesburg: ActionAid International.

Asian Development Bank (ADB, 2014). Environmental issues, climate changes, and energy security in developing Asia. Retrieved from http://www.adb.org/publications/environmentalissues-climate-changes-and-energy-security-developing-asia

Atlantic. (2016). The future of protein will not be animal meat. Retrieved from https://www.youtube.com/watch?v=FR8TFrLYZvM

Caminhos de Diálogo, Curitiba, ano 7, n. 11, p. 172-186, jul./dez. 2019 
Baker, A. (2015 Sept. 07). How climate change is behind the surge of migrants to Europe. Time. Retrieved from http://time.com/4024210/climate-change-migrants/?xid=fbshare

Center for International Environmental Law (CIEL). (1990). "Selected International Legal Materials on Global Warming and Climate Change". American University International Law Review. 5 (2): 515.

Chomsky, N., \& Polk, L. (2013). Nuclear war and environmental catastrophe. New York" Seven Stories Press.

$\begin{array}{llll}\text { Climate } & \text { Reality (2016). Project. } & \text { Retrieved from }\end{array}$ http://www.climaterealityproject.org/blog/climate-change-explained-10-

cartoons?utm_source=email-newsletter\&utm_medium=email\&utm_campaign=General

Conniff, R. (2016 July 03). Global trade: What's a good progressive to do? In The Progressive. Retrieved from www.progressive.org/news/2016/07/188830/global-trade-whats-goodprogressive-do

Crux. (2019 Dec. 12). Vatican calls Greta Thunberg 'great witness' of Church's environmental teaching. https://cruxnow.com/vatican/2019/12/vatican-calls-greta-thunberg-great-witness-ofchurchs-environmental-teaching/

D'Angelo, C. (2016 May 12). Rising sea levels swallow 5 Pacific islands. In The Hufftington Post. Retrieved from http://www.huffingtonpost.com/entry/solomon-islands-swallowedclimate-change_us_5730f200e4b0bc9cb047b77b?slideshow=true

Environmental Protection Energy (2016) Global greenhouse gas emissions data. Retrieved on July 8, 2016 from https://www3.epa.gov/climatechange/ghgemissions/global.html

Fahn, J. D. (2003). A land in fire: The environmental consequences of the Southeast Asian Boom. Chiang Mai, Thailand: Silkworm Books.

Francis. (2015). Laudato si' (On Care for Our Common Home). Vatican.

Freire, P. (1973). Education for critical consciousness. New York: Seabury.

Funk, C. \& Kennedy, B. (2019 April 19). How Americans see climate change in 5 charts. Pew Research Center.

Germanos, A. (2016). Un Assessment: Global destruction of Mother Earth on fast track. Retrieved from http://www.commondreams.org/news/2016/05/20/un-assessment-globaldestruction-mother-earth-fast-

track?utm_campaign=shareaholic\&utm_medium=facebook\&utm_source=socialnetwork

Globall Warming. (2009). 6 major environmental problems of Asia. Retrieved from http://hernadi-key.blogspot.com/2009/02/6-major-environmental-problems-of-asia.html

Goodman, A., \& Goodman, D. (2008). Standing up to the madness: Ordinary heroes in extraordinary times. Westport: Hyperion.

Greenpeace. (2016).The impacts of climate change in China. Retrieved from http://www.greenpeace.org/eastasia/campaigns/climate-energy/problems/impacts/

Guardian. (2019 Dec. 9a). COP25 climate summit: What happened during the first week? https://www.theguardian.com/environment/2019/dec/09/cop25-climate-summit-what-happenedduring-first-week

Guardian. (2019 Dec. 9b). Energy treaty 'risks undermining EU's green new deal." https://www.theguardian.com/business/2019/dec/09/energy-treaty-risks-undermining-eus-greennew-deal

Guardian. (2019 Dec. 1). Poor states 'need extra cash to combat climate crisis threats.' https://www.theguardian.com/environment/2019/dec/01/madrid-climate-talks-poor-nations-sealevels-rising

Guardian. (2019 Nov. 5). Climate crisis: 11,000 scientists warn of "untold suffering." https://www.theguardian.com/environment/2019/nov/05/climate-crisis-11000-scientists-warnof-untold-suffering

Guardian. (2019 Jan. 21). World's 26 richest people own as much as poorest 50\%, says Oxfam. https://www.theguardian.com/business/2019/jan/21/world-26-richest-people-own-as-much-aspoorest-50-per-cent-oxfam-report

Guardian. (2018 Jan. 22). Inequality gap widens as 42 people hold same wealth as $3.7 \mathrm{bn}$ poorest. https://www.theguardian.com/inequality/2018/jan/22/inequality-gap-widens-as-42people-hold-same-wealth-as-37bn-poorest 
Guardian. (2016 March 22). Global warming to hit Asia hardest, warns new report on climate change. Retrieved from https://www.theguardian.com/environment/2014/mar/22/globalwarming-hit-asia-hardest

Guardian. (2015). 60-second climate fix. Retrieved from https://www.facebook.com/theguardian/videos/10153458263351323/

Guardian (20145 December 12). Paris climate deal: Key points at a glance. Retrieved from https://www.theguardian.com/environment/2015/dec/12/paris-climate-deal-key-points

Hershberger, M. (2014 April 16). 6 environmental challenges facing Southeast Asia (and what you can do to help). Retrieved July 11, 2016 from http://matadornetwork.com/change/6environmental-challenges-facing-southeast/

In These Times. (2019 Dec. 13). The U.S. and other rich countries stonewalled $\$ 300$ billion climate relief fund. http://inthesetimes.com/article/22221/u.s.-and-other-rich-countriessuccessfully-stonewalled-300-climate-relief-f

Intergovernmental Panel on Climate Change. (2019 August). Special report on climate change, desertification, land degradation, sustainable land management, food security, and greenhouse gas fluxes in terrestrial ecosystems (SRCCL). https://www.ipcc.ch/srccl-report-downloadpage/

Jamail, D. (2016 May 23). Atmospheric carbon dioxide concentration has passed the point of no return. Retrieved from http://www.truth-out.org/news/item/36133-atmospheric-carbon-dioxideconcentration-has-passed-the-point-of-no-return

Jamail, D. (2016 May 02). As climate disruption advances, UN warns: "The future is happening now." Retrieved from http://www.truth-out.org/news/item/35860-as-climate-disruptionadvances-un-warns-the-future-is-happening-now

Klein, N. (2019) On fire: The burning case for a Green New Deal. Allen Lane: London.

Klein, N. (2018). No is not enough: Defeating the new shock doctrine. Penguin: London.

Klein, N. (2015). This changes everything: Capitalism vs. the climate. Penguin: London.

Klein, N. (2010). No logo. Fourth Estate: New York.

Klein, N. (2008). The shock doctrine: The rise of disaster capitalism. Penguin: London.

Kris, M. E., \& Laccetti, N. (2016). Ministry with the poor in an era of climate change. New World Outlook Magazine (May-June). Also retrievable from The United Methodist Church Global Mission at http://www.umcmission.org/find-resources/new-world-outlookmagazine/2016/may/june/0621eraofclimatechange

McKibben, B. (2016 March 5). The mercury doesn't lie: We've hit a troubling climate change milestone. Boston Globe. www.bostonglobe.com/opinion/2016/03/04/why-degree-temperaturejump-more-important-than-trump-

hands/lCyz5MHZkH8aD0HIDJrcYJ/story.html?event=event25

Merchant, C. (1992). Radical ecology. New York: Routledge, Cahapman \& Hall.

Mosbergen, D. (2016 May 16). Last month was the warmest ever recorded, continuing 7-month hot streak. The Hufftington Post. Retrieved from http://www.huffingtonpost.com/entry/hottestapril-2016-nasa_us_57394f3ae4b060aa781aa334

National Council of Churches in the Philippines. (1995). A public faith, a social witness: Statements and resolutions of the National Council of Churches in the Philippines. Quezon City: NCCP.

Oxfam. (2018 January 22). Richest 1 percent bagged 82 percent of wealth created last year poorest half of humanity got nothing. https://www.oxfam.org/en/press-releases/richest-1percent-bagged-82-percent-wealth-created-last-year-poorest-half-humanity

Oxfam. (2017 January 16). Just 8 men own same wealth as half the world. https://www.oxfam.org/en/press-releases/just-8-men-own-same-wealth-half-world

Oxfam. (2016a January 18). 62 people own the same as half the world. Retrieved from https://www.oxfam.org/en/pressroom/pressreleases/2016-01-18/62-people-own-same-halfworld-reveals-oxfam-davos-report

Oxfam. (2016b June 27). Just five food commodities produce more greenhouse gases than any country except emissions giants China and the US. Retrieved from https://www.oxfam.org/en/pressroom/pressreleases/2016-06-27/just-five-food-commodities-

produce-more-greenhouse-gases-any 
Oxfam. (2014 January 20). Rigged rules mean economic growth increasingly 'winner takes all' for rich elites all over world. https://www.oxfam.org/en/press-releases/rigged-rules-meaneconomic-growth-increasingly-winner-takes-all-rich-elites-all-over

Patz, J.A.; Campbell-Lendrum, D.; Holloway, T.; Foley, J. (17 Nov 2005). "impact of regional climate change on human health." Nature, 438 (7066), pp. 310-317.

Pearce, F. (2016 July 4). What would a global warming increase of 1.5 degrees be like? Yale Environment $360 . \quad$ Retrieved from http://e360.yale.edu/feature/what_would_a_global_warming_increase_15_degree_be_like/3007/ Priebe, M., \& Steinle, F. (2013 February 05). Environmental issues in Southeast Asia. Retrieved from http://www.fairobserver.com/region/central_south_asia/environmental-issues-southeastasia/

Readfearn, G. (2016). Conservative funders of climate denials are quietly spending millions to generate more partisan journalism. http://www.desmogblog.com/2016/06/16/conservativefunders-climate-denial-are-quietly-spending-millions-create-more-partisan-journalism

Roberts, W. (2016). 30 ways cities can prepare for global warning. Retrieved from http://www.countercurrents.org/2016/07/08/30-ways-cities-can-prepare-for-global-warming/

Rockström, J. et. al. (2017). A roadmap for rapid decarbonization. Science.

Schwägerl, C. (2016). Vanishing act: Why insects are declining and why it matters. Retrieved from http://www.countercurrents.org/2016/07/08/vanishing-act-why-insects-are-declining-andwhy-it-matters/

Shiva, V. (2013). "Development, ecology, and women." In J. Plant (Ed.), Healing the wounds: The promise of ecofeminism. Philadelphia \& Sta. Cruz, CA: New Society Publishers.

Todhunter, C. (2016). On World Environment Day: Profiting from Death, Devastation and Destruction is the Norm. Montreal, Canada: Center for Research on Globalization. Retrieved from http://www.globalresearch.ca/on-world-environment-day-profiting-from-deathdevastation-and-destruction-is-the-norm/5529090

Ty, R. (2011). Human rights, conflict transformation, and peacebuilding: The state, NGOs, social movements, and civil society-The struggle for power, social justice, and social change. DeKalb, IL: Northern Illinois University.

United Nations. (2015). Paris Agreement. Geneva and New York: United Nations. Retrievable from https://treaties.un.org/pages/ViewDetails.aspx?src=TREATY\&mtdsg_no=XXVII-7$\mathrm{d} \&$ chapter $=27 \&$ lang=en

United Nations Framework Convention on Climate Change. (2019).UN climate change conference - December 2019. https://unfccc.int/

United Nations Ksentini Report. (1994). Draft Principles On Human Rights And The Environment, E/CN.4/Sub.2/1994/9, Annex I (1994). Retrieved from http://hrlibrary.umn.edu/instree/1994-dec.htm

United Nations. (1992a). Agenda 21. New York and Geneva: United Nations.

United Nations. (1992b). Rio Declaration on Environment and Development. New York and Geneva: United Nations.

World Council of Churches. (2012 December 7). The world cannot wait: Climate change is happening! Geneva: World Council of Churches.

World Development Movement. (2009 November). The climate debt crisis: Why paying our dues is essential for tackling climate change. London: World Development Movement.

World Meteorological Organizations (WMO) (2019 Nov 25). The state of greenhouse gases in the atmosphere based on global observations through 2018. Greenhouse gas bulletin. No. 15. Geneva: United Nations WMO.

Worldometers. (2016). Environment. Retrieved July $11 \mathrm{~m} \quad 2016$ from http://www.worldometers.info/

Yale Environment 360. (2016 June 28). Atmospheric CO2 Level May Not Drop Below 400 ppm "Within Our Lifetimes." Retrieved from http://www.countercurrents.org/2016/06/28/atmospheric-co2-level-may-not-drop-below-400ppm-within-our-lifetimes/

Yes! Magazine. (2019 May 15). Reminder: Climate change was no accident. https://www.yesmagazine.org/opinion/2019/05/15/climate-change-was-no-accidentcorporations/ 